\title{
Variability in oil tocopherol concentration and composition of traditional and high oleic sunflower hybrids (Helianthus annuus L.) in the Pampean region (Argentina)
}

\author{
By Susana M. Nolasco ${ }^{1}$, Luis A.N. Aguirrezábal ${ }^{2}$, Julia Lúquez ${ }^{2}$ and Carmen Mateo
}

${ }^{1}$ Departamento de Ingeniería Química, Facultad de Ingeniería, Universidad Nacional del Centro de la Provincia de Buenos Aires, Avda. del Valle 7537, B7400JWI-Olavarría, Argentina.

Tel./Fax: 54-2284451055/56, e-mail: snolasco @ fio.unicen.edu.ar

${ }^{2}$ Departamento de Producción Vegetal, Suelos e Ingeniería Rural, Unidad Integrada Facultad

de Ciencias Agrarias de la Universidad Nacional de Mar del Plata-INTA Balcarce, Ruta 226, km 73,5, cc 276, (7620), Balcarce, Argentina. Tel/Fax: 54-2266439100/101, e-mail: jluquez @ balcarce.inta.gov.ar.

\section{RESUMEN}

Variabilidad en la concentración y composición de los tocoferoles en el aceite de híbridos de girasol tradicionales y "alto oleico" en Argentina.

Los tocoferoles son antioxidantes naturales que aumentan la estabilidad de los aceites y cumplen una importante actividad biológica en humanos. No son conocidos estudios sobre la variabilidad del contenido y composición de tocoferoles en el aceite de híbridos de girasol tradicionales (HT) y "alto oleico" (HAO) sembrados en diferentes ambientes en Argentina. El objetivo de este trabajo fue detectar y examinar esa variabilidad. Las semillas fueron obtenidas de a) $7 \mathrm{HT}$ sembrados en 4 localidades (Experimento I), y, b) 5 híbridos ( 3 $\mathrm{HAO}$ y $2 \mathrm{HT}$ ) sembrados en 3 localidades (Experimento II). La concentración de tocoferoles totales varió entre 634 y $1054 \mu \mathrm{g} \mathrm{g}$ aceite $^{-1}$. El $\alpha$-tocoferol aportó con el 90.8 a $97.0 \%$ del contenido total de tocoferol. Las concentraciones de $\alpha$-tocoferol y tocoferol total estuvieron genéticamente determinadas (más del $80 \%$ ). Para ambas variables, la interacción híbrido $x$ localidad en el Experimento I fue significativa aunque de pequeño valor. La concentración media de tocoferoles totales entre ambientes y en cada ambiente fue mayor en los $\mathrm{HAO}$ que en los HT en el Experimento II, mientras que no hubo diferencias significativas entre $\mathrm{HAO}$ ni entre ambientes para esta variable, ni para $\alpha$-tocoferol. En ambos experimentos, la variabilidad en la concentración de tocoferoles para cada híbrido a través de los ambientes fue más alta que la ocurrida entre híbridos en un mismo ambiente. Para obtener aceite de girasol con alta concentración de tocoferoles deben seleccionarse tanto el genotipo como el ambiente.

PALABRAS-CLAVE: Aceite - Alto oleico - Girasol - Helianthus annuus L. - Tocoferol - Variabilidad.

\section{SUMMARY}

Variability in oil tocopherol concentration and composition of traditional and high oleic sunflower hybrids (Helianthus annuus L.) in the Pampean region (Argentina).

Tocopherols are natural antioxidants that increase the stability of food fat and fulfill an important biological requirement in humans. There are no previous studies on the variability of tocopherol concentration and composition in the oil of sunflower traditional hybrids (TH) and high oleic sunflower hybrids $(\mathrm{HOH})$ from different environments in Argentina. The objective of this work was to detect and examine that variability. Seed samples were obtained from i) seven $\mathrm{TH}$ grown in four locations (Experiment I) and, ii) five hybrids (three $\mathrm{HOH}$ and two traditional ones) grown in three locations (Experiment II). Concentrations of total tocopherol in oil ranged from 634 to $1054 \mu \mathrm{g} \mathrm{g} \mathrm{oil}{ }^{-1}$. $\alpha$-tocopherol accounted for 90.8 to $97 \%$ of the total tocopherols. Total and $\alpha$-tocopherol concentrations were highly genetically determined (more than $80 \%$ ). In Experiment I, a significant, although low in value, interaction between hybrid and location was found for total and $\alpha$-tocopherol concentrations. In Experiment II, mean values for total tocopherol concentration in $\mathrm{HOH}$ and in each environment were larger than in TH. Significant differences for total and $\alpha$-tocopherol concentration were not found among $\mathrm{HOH}$ and environments. The variation of tocopherol concentration for each hybrid across environments was higher than the variation among hybrids in the same environment. To obtain oil with high tocopherol concentration, both hybrid and environment must be selected.

KEY-WORDS: Helianthus annuus L - High oleic - Oil Sunflower - Tocopherols - Variability.

\section{INTRODUCTION}

Tocopherols are natural compounds having vitamin $\mathrm{E}$ activity. Higher animals cannot synthetise vitamin E, so they need it in their food. Tocopherols also protect lipids in fats and oils along with protecting food from oxidation. A part of the tocopherols is lost during sunflower oil proccesing (Eitenmiller, 1997; Bramley et al., 2000). Therefore, it is important to obtain oils with high tocopherol content.

Tocopherols occur in plants as a family of four derivatives named $\alpha-, \beta-, \gamma-$ and $\delta$-tocopherol. Tocopherols differ in their relative in vitro and in vivo antioxidant activities (Kamal-Eldin and Appelquist, 1996).

The total tocopherol concentration in oil of sunflower traditional hybrids, $\mathrm{TH}$, (with a tipical oleic acid content lower than $30 \%$ ) typically ranges from 447 and $900 \mu \mathrm{g} \mathrm{g} \mathrm{oil}{ }^{-1}$ (Gustone et al., 1994) with extreme values varying from 389 to $1873 \mu \mathrm{g} \mathrm{g} \mathrm{oil}{ }^{-1}$ (Nagao and Yamazaki, 1983; Dorrell and Vick, 
1997; Miller and Fick, 1997; Cole et al., 1998; Dolde et al., 1999; Velasco et al., 2002).

Few studies have considered tocopherol concentrations and their variability in the oil of $\mathrm{TH}$ and high oleic sunflower hybrids, $\mathrm{HOH}$ (with a tipical oleic acid content higher than $70 \%$ ). Genetic variability (Demurin et al., 1996) and genetic and environmental variability in the relative proportion of different tocopherols in traditional sunflower oil were observed (Velasco et al., 2002). De Villiers et al. (1989) found higher tocopherol concentration in two $\mathrm{HOH}\left(895-1002 \mu \mathrm{g} \mathrm{g} \mathrm{oil}^{-1}\right)$ than in TH (710-790 $\mu \mathrm{gg} \mathrm{oil}^{-1}$ ) while Mascioli (2001) didn't find any differences among $\mathrm{HOH}$, $\mathrm{TH}$ and middle oleic hybrids (tipical oleic acid content between 50 and $70 \%)$.

Studies of variability in grain yield, oil content and oleic acid content (Aguero et al., 1999) and of stability and adaptability in grain yield and quality traits in $\mathrm{HOH}$ (Lúquez et al., 2002) have recently been assessed for several genotypes in the Argentine High Oleic Sunflower Trials. However, there are no studies on the variability of tocopherol concentration and composition in the oil of $\mathrm{TH}$ and $\mathrm{HOH}$ in the Pampean Region, which is the principal area where sunflowers are cultivated (ASAGIR, 2003). Argentina is the world biggest sunflower oil exporter.

The objective of this work was to detect and examine the variability of tocopherol concentration and composition in oil of traditional and high oleic sunflower hybrids cultivated in different locations in the Pampean Region, in Argentina.

\section{EXPERIMENTAL}

\subsection{Plant materials}

Two groups of sunflower, Helianthus annuus L. hybrids with different potential content of oleic acid: $\mathrm{TH}$ and $\mathrm{HOH}$, were evaluated for grain yield $(\mathrm{kg}$ $\mathrm{ha}^{-1}$ ), oil content (\%) and tocopherol concentrations in the oil $\left(\mu \mathrm{g} \mathrm{g} \mathrm{oil}{ }^{-1}\right)$ in two experiments.

Experiment I: It consisted of $7 \mathrm{TH}$ belonging to the official comparative Yield Trials from Buenos Aires and La Pampa provinces: the stripped hull hybrids ACA 884, Morgan 742 and Pyramid-1, and the black hull hybrids, Contiflor 11, Jaguel, Paraíso 20 , and Rancul. These hybrids were provided by Asociación de Cooperativas Argentinas; Mycogen S.A, Cargill S.A.; Zéneca S.A.; Trébol Sur S.A.; Nidera S.A., and Novartis S.A., respectively.

Experiment II: It consisted of 3 commercial $\mathrm{HOH}$ belonging to the official High Oleic Yield Trials from Buenos Aires province, and $2 \mathrm{TH}$ (testers). The $\mathrm{HOH}$ were Trisum 870, Aromo and Sideral, provided by Mycoyen S.A., Nidera S.A. and Sursem S.A., respectively, and the TH were ACA 884 and Contiflor 9 (Mycoyen S.A.).

\subsection{Field trials}

Field trials for Experiment I were conducted at four locations: Balcarce $\left(37^{\circ} 45^{\prime} \mathrm{S}, 58^{\circ} 18^{\prime} \mathrm{W}\right)$, Bordenave $\left(37^{\circ} 51^{\prime} \mathrm{S}, 63^{\circ} 01^{\prime} \mathrm{W}\right)$, Tandil $\left(37^{\circ} 14^{\prime} \mathrm{S}\right.$, $\left.59^{\circ} 15^{\prime}\right)$ and Realicó ( $\left.34^{\circ} 58^{\prime} \mathrm{S}, 64^{\circ} 58^{\prime}\right)$, while field trials for Experiment II were conducted in three locations (Pieres, $38^{\circ} 29^{\prime} \mathrm{S}, 58^{\circ} 50^{\prime} \mathrm{W}, 9$ de Julio, $35^{\circ} 27^{\prime} \mathrm{S}, 60^{\circ} 53^{\prime} \mathrm{W}$ and Tres Arroyos, $38^{\circ} 20^{\prime} \mathrm{S}$, $\left.60^{\circ} 15^{\prime} \mathrm{W}\right)$.

All experimental sites are located in the main sunflower-growing region of Argentina, the Pampean Region. Locations were selected because of contrasting mean meteorological conditions during the sunflower growing season (Table I) and because yield trials conducted in these locations in previous years presented large differences in mean yield (Pereyra, personal communication). The experimental design applied on each site was a completely random block design with three replicates in Experiment I and two replicates in Experiment II. Each plot consisted of six 6-m- long furrows, $0.70 \mathrm{~m}$ apart. Plant density was $71500 \mathrm{pl} / \mathrm{ha}$. Harvesting was done when seeds had a humidity of $11 \%$.

\subsection{Measurements and data analysis}

\subsubsection{Grain yield}

This trait was determined in the central furrow of each plot and expressed in $\mathrm{kg} \mathrm{ha}^{-1}$.

Table I

Daily mean, maximum and minimum average temperatures calculated for the sunflower growing season (November-March, 1971-1990), and cumulated annual rainfall (1971-1990) for locations where field trial were conducted. Data ${ }^{1}$ Experiment I, ${ }^{2}$ Experiment II.

\begin{tabular}{lcccc}
\hline Location & Mean $\left({ }^{\circ} \mathbf{C}\right)$ & Maximum $\left({ }^{\circ} \mathbf{C}\right)$ & Minimum $\left({ }^{\circ} \mathbf{C}\right)$ & Rainfall $(\mathbf{m m})$ \\
\hline Balcarce $^{1}$ & 18.7 & 25.9 & 12.6 & 886.9 \\
Bordenave $^{1}$ & 20.1 & 27.6 & 13.1 & 713.9 \\
Tandil $^{1}$ & 18.8 & 25.5 & 12.4 & 940.8 \\
Realicó $^{1}$ & 22.6 & 31.3 & 14.3 & 797.1 \\
Pieres $^{2}$ & 19.4 & 26.6 & 11.6 & 975.0 \\
de Julio $^{2}$ & 21.6 & 28.2 & 14.9 & 1079.1 \\
Tres Arroyos $^{2}$ & 19.1 & 26.5 & 12.8 & 814.9 \\
\hline
\end{tabular}




\subsubsection{Oil content}

This trait was determined by NMR (Nuclear Magnetic Resonance) (Robertson and Morrison, 1979) in grains harvested from free-pollinating plants from the central furrow of each plot with an Analyser Magnet Type 10 (Newport Oxford Instruments, Buckinghamshire, England; 37), according to AOCS Ai 2-75 method (1998). Oil concentration was expressed on a dry weight basis. Moisture content was determined according to the Association of Official Chemists methods (AOAC, 1990).

\subsubsection{Tocopherol concentrations in the oil}

Seeds of self fed plants were ground in a mill and extracted with n-hexane (Soxthel), first at room temperature for 4 hours, and at $69^{\circ} \mathrm{C}$ for the next 4 hours. The solvent was evaporated in a rotary vacuum evaporator at $40^{\circ} \mathrm{C}$. Tocopherol contents of crude oils were determined by normal phase HPLC using the Hewlett Packard chromatography system (HP 1059 Series, Waldbronn, germany) with a LiChrosorb Sil $60(5 \mu \mathrm{m}, 250 \mathrm{~mm} \times 4.00 \mathrm{~mm}$, Merck, Darmstadt, Germany) column. Approximately $0.5 \mathrm{~g}$ of each oil was dissolved in $5 \mathrm{ml}$ of the mobile phase. Twenty micro liter samples were injected for each determination. The column was eluted with nhexane: isopropanol (99.5:0.5, 99.3:0.7 v/v, HPLC solvent, J.T. Baker, Phillpsburg, USA) at a flow rate of $1.5 \mathrm{ml} \mathrm{min}{ }^{-1}$. Tocopherols were detected by absorbance at $292 \mathrm{~nm}$ with an ultraviolet-visible detector (HP 1050 Series) and measured using a six-point external standard curve (A.O.C.S., 1998).

\subsection{Statistical analyses}

Means and standard deviations for grain yield, oil content and total and individual tocopherol concentrations were calculated.

An analysis of variance for a random complete block design (RCBD) combined across locations was performed for total and individual tocopherol concentrations. Hybrids, locations and the hybrid per location interactions were considered as random effects.

Genetic Determination Degree (GDD) was calculated for tocopherol concentration in the oil in order to know the proportion of phenotypic variation determined by genetic effects among sunflower hybrids. GDD was calculated as proposed by Mariotti (1986) and Fehr (1987):

$$
\mathrm{GDD}=\frac{\sigma^{2} G}{\sigma^{2} G+\left(\sigma^{2} H L I\right) / I+\left(\sigma^{2} E\right) / /^{\star} r}
$$

where: $\sigma^{2} \mathbf{G}$ is the genotypic variance among hybrids, $\sigma^{2}$ HLI the variance of hybrid * location interactions, $\sigma^{2} \mathbf{E}$ the error variance, I the number of locations, and $\mathbf{r}$ the number of replicates.
Regression analysis was used to determine the relationships between tocopherol concentration in oil and other variables in seeds (software Sigma Plot for Windows, version 4.10, SPSS, 1997).

Coefficients of variation (CV\%) in the grain yield and the oil content were calculated, among hybrids and locations to analyze variations in tocopherol concentrations.

\section{RESULTS AND DISCUSSION}

\subsection{Grain yield}

\section{Experiment I}

Mean grain yield was $2705.4 \mathrm{~kg} \mathrm{ha}^{-1}$ (CV = $32.2 \%$ ). In this experiment, grain yield ranged from 1865.5 in Tandil to $3552.0 \mathrm{~kg} \mathrm{ha}^{-1}$ in Balcarce. This maximum grain yield is higher than the best average on farm yield (Mercau et al., 2001). Among hybrids, grain yield varied from $2398.7 \mathrm{~kg} \mathrm{ha}^{-1}$ for Jaguel to $2964.3 \mathrm{~kg} \mathrm{ha}^{-1}$ for Paraíso 20 (Table Ila).

\section{Experiment /I}

Mean grain yield was $2323.2 \mathrm{~kg} \mathrm{ha}^{-1}(\mathrm{CV}=$ $22.4 \%$ ). Grain yield ranged from $2175.7 \mathrm{~kg} \mathrm{ha}^{-1}$ in Pieres to $2488.2 \mathrm{~kg} \mathrm{ha}^{-1}$ in 9 de Julio. Among hybrids, grain yield varied from $1636.7 \mathrm{~kg} \mathrm{ha}^{-1}$ and $2892.3 \mathrm{~kg} \mathrm{ha}^{-1}$ for Sideral $(\mathrm{HOH})$ and ACA $884(\mathrm{TH})$ respectively. Grain yield variation among hybrids for each location was greater than variation among locations. On average, $\mathrm{TH}$ yielded more than $\mathrm{HOH}$ (2640.0 vs. $1866.2 \mathrm{~kg} \mathrm{ha}^{-1}$ ). Grain yield variation across locations in $\mathrm{HOH}$ was greater than $\mathrm{TH}$ variation ( $\mathrm{CV}=18.5$ and $9 \%$, respectively) (Table IIIa).

Grain yields registered in both experiments are frequently obtained in production fields in Argentina. The average grain yield obtained is higher than the average grain yield obtained in Argentina (1862 $\mathrm{kg} \mathrm{ha}^{-1}$ for the period 1985-1998, CIARA, 1998)

\subsection{Oil content}

\section{Experiment I}

Mean oil content was $48.1(\mathrm{CV}=5.5 \%)$. This value is higher than the commercialization basis in Argentina (42\%). Oil content ranged from $45.9 \%$ in Tandil to $49.4 \%$ in Bordenave. Among hybrids, oil content varied from $45.9 \%$ for Morgan 734 to $50.7 \%$ for Paraíso 20 (Table Ilb). The oil content of black hull hybrids ranged from $47.8 \%$ to $50.7 \%$ while for stripped hull it ranged from $45.8 \%$ to $46.7 \%$.

\section{Experiment II}

Mean oil content was $44.6 \%(\mathrm{CV}=4.8 \%)$. It ranged from $43.5 \%$ in 9 de Julio to $45.4 \%$ in Tres Arroyos. Oil content varied among hybrids between 
Table II

(a). Grain yield $\left(\mathrm{kg} \mathrm{ha}^{-1}\right)$ and (b) Oil content (\% d.b.) for each hybrid and four locations in Experiment I. B: Black hull hybrid, S: Stripped hull hybrid

(a) Grain yield

\begin{tabular}{|c|c|c|c|c|c|}
\hline \multirow{2}{*}{ Hybrids } & \multicolumn{4}{|c|}{ Location } & \multirow{2}{*}{ Average } \\
\hline & Balcarce & Bordenave & Realicó & Tandil & \\
\hline Paraíso 20 & 4969.3 & 3026.0 & 1955.0 & 1906.7 & 2964.3 \\
\hline Pyramid-1 & 3224.0 & 2856.0 & 2207.7 & 2136.3 & 2606.0 \\
\hline Morgan 742 & 3241.3 & 3822.0 & 2705.7 & 1880.7 & 2912.4 \\
\hline Contiflor 11 & 3393.0 & 3427.3 & 1625.3 & 1911.0 & 2589.2 \\
\hline Rancul & 3206.7 & 3434.0 & 2034.3 & 1778.7 & 2613.4 \\
\hline ACA 884 & 3830.7 & 3400.0 & 2324.3 & 1859.0 & 2853.5 \\
\hline Jaguel & 2998.7 & 3523.7 & 1486.3 & 1586.0 & 2398.7 \\
\hline Average & 3552.0 & 3355.6 & 2048.4 & 1865.5 & \\
\hline \multicolumn{6}{|l|}{ (b) Oil content } \\
\hline \multirow{2}{*}{ Hybrids } & \multicolumn{4}{|c|}{ Location } & \multirow{2}{*}{ Average } \\
\hline & Balcarce & Bordenave & Realicó & Tandil & \\
\hline Paraíso 20, & 52.2 & 53.7 & 48.6 & 48.3 & 50.7 \\
\hline Pyramid-1,s & 48.3 & 47.9 & 46.5 & 44.2 & 46.7 \\
\hline Morgan $742, \mathrm{~s}$ & 45.8 & 46.0 & 48.8 & 42.8 & 45.9 \\
\hline Contiflor $11^{, B}$ & 47.8 & 49.0 & 47.5 & 46.9 & 47.8 \\
\hline Rancul'B $^{\text {,B }}$ & 50.0 & 52.9 & 47.0 & 49.0 & 49.7 \\
\hline ACA $884^{, S}$ & 46.7 & 46.6 & 48.6 & 42.2 & 46.0 \\
\hline Jaguel $^{, \mathrm{B}}$ & 50.7 & 50.0 & 49.6 & 48.1 & 49.6 \\
\hline Average & 48.8 & 49.4 & 48.1 & 45.9 & \\
\hline
\end{tabular}

Table III

Grain yield (kg ha $\left.{ }^{-1}\right)$ and (b) Oil content (\% d.b.) for each hybrid and four locations in Experiment II. B: Black hull hybrid. S: Stripped hull hybrid. T: traditional hybrid, $\mathrm{HOH}$, High oleic hybrid

(a) Grain yield

\begin{tabular}{|c|c|c|c|c|}
\hline \multirow{2}{*}{ Hybrids } & \multicolumn{3}{|c|}{ Location } & \multirow{2}{*}{ Average } \\
\hline & Pieres & 9 de Julio & Tres Arroyos & \\
\hline Sideral & 1614 & 1994 & 1302 & 1637 \\
\hline Trisum & 1914 & 2392 & 2184 & 2163 \\
\hline Aromo & 2071 & 2683 & 2378 & 2377 \\
\hline Contiflor 9 & 2723 & 2694 & 2225 & 2547 \\
\hline ACA 884 & 2558 & 2679 & 3441 & 2892 \\
\hline Average & 2176 & 2488 & 2306 & \\
\hline \multicolumn{5}{|l|}{ (b) Oil content } \\
\hline \multirow{2}{*}{ Hybrids } & \multicolumn{3}{|c|}{ Location } & \multirow{2}{*}{ Average } \\
\hline & Pieres & 9 de Julio & Tres Arroyos & \\
\hline Sideral $^{\mathrm{HOH}, \mathrm{B}}$ & 48.1 & 44.0 & 48.2 & 46.8 \\
\hline Trisum $^{\mathrm{HOH}, \mathrm{B}}$ & 42.7 & 42.0 & 44.4 & 43.0 \\
\hline Aromo ${ }^{\mathrm{HOH}, \mathrm{B}}$ & 47.6 & 44.6 & 46.7 & 46.3 \\
\hline Contiflor $9^{\mathrm{T}, \mathrm{B}}$ & 44.2 & 45.1 & 44.2 & 44.5 \\
\hline ACA $884^{\mathrm{T}, \mathrm{S}}$ & 42.0 & 41.8 & 43.7 & 42.5 \\
\hline Average & 44.9 & 43.5 & 45.4 & \\
\hline
\end{tabular}


42.5 for ACA 884 and 46.8 for Sideral. Mean $\mathrm{HOH}$ oil content was greater than TH oil content (45.3 vs. 43.5\%) (Table IIlb).

As expected, in both experiments, mean oil content in black hull hybrids (high oil content potential, $47.3 \%$ ) was higher than in the stripped hull variety (low oil content potential $45.3 \%$ ).

\subsection{Tocopherol concentrations in oil}

\section{Experiment I}

The total tocopherol concentration mean was $826 \mu \mathrm{g} \mathrm{g} \mathrm{oil}^{-1}(\mathrm{CV}=12.8 \%)$ and ranged from 708 to $936 \mu \mathrm{g} \mathrm{g} \mathrm{oil}{ }^{-1}$ in Realicó and Tandil respectively. In sunflower, Purdy (1986) and Dorrell and Vick (1997) reported values that ranged from 570 to $770 \mu \mathrm{g} \mathrm{g}$ $\mathrm{oil}^{-1}$. Total tocopherol concentration varied from 765 and $938 \mu \mathrm{g} \mathrm{g} \mathrm{oil}{ }^{-1}$ for Jaguel and Paraíso 20 respectively (Table IVa). CV (12.8\%) of tocopherol content was higher than CV of oil content $(5.5 \%)$ but lower than $\mathrm{CV}$ of grain yield $(32.2 \%)$, this last trait was considered highly variable. The $\mathrm{CV}$ of tocopherol content in this experiment was lower than the CV of $23 \%$ calculated from data obtained by Nagao and Yamazaki (1983), who worked with different genotypes and environments in Japan. Also, it was close to the CV of $19 \%$ obtained by Jáky et al. (1980), who worked with sunflower varieties from Hungary and Russia, and higher than the CV $=7.4 \%$ obtained by Kandil et al. (1990), who worked with different sunflower hybrids in contrasting environments (Germany and Egypt, summer and winter).

$\alpha$-tocopherol and $\beta$-tocopherol were detected in all samples while $\gamma$-tocopherol was only detected in $31 \%$ of the samples. The $\alpha$-tocopherol concentration mean was $791 \mathrm{ug} \mathrm{g} \mathrm{oil}^{-1}$ and represented the major proportion of total tocopherols (90.8\%) (Table IVb). $\beta$-tocopherol and $\gamma$-tocopherol concentrations were 32.0 and $4.5 \mu \mathrm{g} \mathrm{g}$ $\mathrm{oil}^{-1}$ and represented 3.9 and less of $1 \%$ of the total tocopherols respectively (Tables IVc and d).

\section{Experiment /I}

Mean total tocopherol concentration was $840 \mu \mathrm{g}$ $\mathrm{g} \mathrm{oil}^{-1}(\mathrm{CV}=8.4 \%)$ and ranged from 795 to $870 \mu \mathrm{g}$ $\mathrm{g} \mathrm{oil}{ }^{-1}$ in 9 de Julio and Tres Arroyos respectively. Total tocopherol concentrations varied from 776 and $926 \mu \mathrm{g} \mathrm{g} \mathrm{oil}{ }^{-1}$ for ACA 884 and Sideral respectively. In $\mathrm{HOH}$, this trait was higher than the $\mathrm{TH}$ mean (875 vs. $786 \mu \mathrm{g} \mathrm{g} \mathrm{oil}{ }^{-1}$ ) in each location (Table Va).

The CV value ( $8.4 \%)$ was higher than the CV of oil content $(4.8 \%)$ but lower than the grain yield $(\mathrm{CV}=22.4 \%)$. It was also lower than in Experiment I. Mean values for this trait in $\mathrm{HOH}$ and $\mathrm{TH}$ were similar to those found by De Villiers et al. (1989), who reported $949 \mathrm{ug} \mathrm{g} \mathrm{oil}^{-1}$ in two $\mathrm{HOH}$ in relation to $710-790 \mu \mathrm{g} \mathrm{g} \mathrm{oil}^{-1}$ in TH. However, Holló et al. (1998) reported no differences in the composition and concentration of tocopherols in the oil of $\mathrm{TH}$ and $\mathrm{HOH}$. Mascioli (2001) reported no differences in tocopherol concentrations in the oil among one $\mathrm{TH}$, one $\mathrm{HOH}$ and one hybrid with a medium oleic acid content.

$\alpha$-tocopherol and $\beta$-tocopherol were detected in all samples. $\alpha$-tocopherol mean concentration was $815 \mu \mathrm{g} \mathrm{g} \mathrm{oil}{ }^{-1}$ and represented the highest proportion of total tocopherols (97\%). $\beta$-tocopherol concentration was $25.4 \mu \mathrm{g} \mathrm{g} \mathrm{oil}{ }^{-1}$ and represented $3.0 \%$ of the total tocopherols (Table $\mathrm{Va}$ and $\mathrm{b}$ ). It was not possible to measure the $\gamma$-tocopherol concentration. Only small traces were detected in $23 \%$ of the samples.

Relative $\alpha$ - and $\beta$-tocopherol concentrations with respect to total tocopherol concentration were similar in $\mathrm{TH}$ and $\mathrm{HOH}$.

In both experiments, some of samples $(25 \%$ in Experiment I and $13 \%$ in Experiment II) showed tocopherol content values higher than those reported by Gustone et al. (1994) as typical values of Helianthus annuus. Extreme values for this trait were close to results reported by Marquard, (1990) (480 to $1128 \mu \mathrm{g} \mathrm{g} \mathrm{oil}^{-1}$ ) while maximum values were lower than the values found by Velasco et al., (2002) (562.8 to $\left.1872.8 \mu \mathrm{g} \mathrm{g} \mathrm{oil}{ }^{-1}\right)$.

In both experiments, the $\alpha$-tocopherol concentration represented the highest proportion of total tocopherol concentrations. These results are similar to those reported by Demurin et al. (1996); Dorrell and Vick (1997); Miller and Fick (1997) and Cole et al. (1998).

\subsection{Variance analysis and Genetic Determination Degree (GDD) determination of tocopherol concentrations in the oil}

\subsubsection{General}

Error Mean square (EMS) at Bordenave was 7.5 higher than the minor EMS in other experimental locations. Therefore, in order to avoid distortions in the results (Box,1954; Cochran and Cox, 1992), this location was not considered for the combined ANOVA.

\subsubsection{Total tocopherol}

\section{Experiment I}

Significant $(P \leq 0.01)$ differences among hybrids and among locations $(P \leq 0.0001)$ were detected. Hybrid*Location interaction (HLI) was significant $(P \leq 0.0034)$, meaning that some hybrids showed different ranking in different locations. This interaction, however, had a low value.

Calculated GDD was $77.6 \%$, which showed that $77.6 \%$ of the phenotypic variation observed among hybrids was a genotypic variation.

CV (\%) values across locations for each hybrid ranged from 8.4 to18.3\%, while CV (\%) values 
Table IV

(a) total tocopherol, (b) $\alpha$-tocopherol, (c) $\beta$-tocopherol and (d) $\gamma$-tocopherol in oil ( $\mu \mathrm{g} \mathrm{g}$ oil-1 ) for each hybrid and four locations in Experiment I

(a) total tocopherol

\begin{tabular}{lccccc}
\hline \multirow{2}{*}{ Hybrids } & \multicolumn{4}{c}{ Location } & \multirow{2}{*}{ Average } \\
\cline { 2 - 5 } & Balcarce & Bordenave & Realicó & Tandil & 938 \\
\hline Paraíso 20 & 935 & 987 & 777 & 1054 & 876 \\
Pyramid-1 & 841 & 868 & 807 & 987 & 821 \\
Morgan 742 & 820 & 827 & 634 & 1002 & 804 \\
Contiflor 11 & 865 & 778 & 688 & 885 & 790 \\
Rancul & 818 & 799 & 695 & 847 & 788 \\
ACA 884 & 734 & 7810 & 657 & 867 & 765 \\
Jaguel & 753 & 836 & 708 & 936 & \\
\hline Average & 824 & & & & \\
\hline
\end{tabular}

(b) $\alpha$-tocopherol

\begin{tabular}{lccccc}
\hline \multirow{2}{*}{ Hybrids } & \multicolumn{4}{c}{ Location } & Average \\
\cline { 2 - 5 } & Balcarce & Bordenave & Realicó & Tandil & 906 \\
\hline Paraíso 20 & 887 & 957 & 756 & 1022 & 833 \\
Pyramid-1 & 794 & 821 & 780 & 936 & 787 \\
Morgan 742 & 783 & 805 & 621 & 940 & 773 \\
Contiflor 11 & 820 & 752 & 671 & 849 & 761 \\
Rancul & 775 & 771 & 680 & 819 & 753 \\
ACA 884 & 694 & 767 & 677 & 875 & 725 \\
Jaguel & 705 & 839 & 635 & 822 & \\
\hline Average & 780 & 802 & 689 & 895 &
\end{tabular}

(c) $\beta$-tocopherol

\begin{tabular}{|c|c|c|c|c|c|}
\hline \multirow{2}{*}{ Hybrids } & \multicolumn{4}{|c|}{ Location } & \multirow{2}{*}{ Average } \\
\hline & Balcarce & Bordenave & Realicó & Tandil & \\
\hline Paraíso 20 & 43 & 30 & 21 & 32 & 31.5 \\
\hline Pyramid-1 & 46 & 44 & 27 & 47 & 41.0 \\
\hline Morgan 742 & 35 & 22 & 13 & 53 & 30.8 \\
\hline Contiflor 11 & 31 & 25 & 12 & 35 & 25.8 \\
\hline Rancul & 32 & 23 & 15 & 27 & 24.3 \\
\hline ACA 884 & 37 & 40 & 22 & 36 & 33.8 \\
\hline Jaguel & 42 & 42 & 22 & 41 & 36.8 \\
\hline Average & 38.0 & 32.3 & 18.9 & 38.7 & \\
\hline
\end{tabular}

(d) $\gamma$-tocopherol

\begin{tabular}{|c|c|c|c|c|c|}
\hline \multirow{2}{*}{ Hybrids } & \multicolumn{4}{|c|}{ Location } & \multirow{2}{*}{ Average } \\
\hline & Balcarce & Bordenave & Realicó & Tandil & \\
\hline Paraíso 20 & 5.3 & - & - & - & 5.3 \\
\hline Pyramid-1 & 0 & 3.7 & - & 0.8 & 1.5 \\
\hline Morgan 742 & 2.3 & - & - & 9.0 & 5.7 \\
\hline Contiflor 11 & 14.0 & 1.0 & - & 0.8 & 5.3 \\
\hline Rancul & 10.7 & 5.0 & - & 2 & 5.9 \\
\hline ACA 884 & 3.0 & 3.7 & - & - & 3.4 \\
\hline Jaguel & 6.0 & - & - & 3.7 & 4.9 \\
\hline Average & 5.9 & 3.4 & - & 3.3 & \\
\hline
\end{tabular}


Table $\mathrm{V}$

(a) total tocopherol, (b) $\alpha$-tocopherol and, (c) $\beta$-tocopherol in oil ( $\left.\mu \mathrm{g} \mathrm{g} \mathrm{oil}^{-1}\right)$ for each hybrid and three locations in Experiment II (TH and $\mathrm{HOH}$ )

(a) total tocopherol

\begin{tabular}{|c|c|c|c|c|}
\hline \multirow{2}{*}{ Hybrids } & \multicolumn{3}{|c|}{ Location } & \multirow{2}{*}{ Average } \\
\hline & Pieres & 9 de Julio & Tres Arroyos & \\
\hline Sideral & 925 & 910 & 942 & 926 \\
\hline Trisum & 923 & 774 & 895 & 864 \\
\hline Aromo & 855 & 775 & 879 & 836 \\
\hline Contiflor 9 & 759 & 798 & 833 & 797 \\
\hline ACA 884 & 812 & 716 & 799 & 776 \\
\hline Average & 855 & 795 & 870 & \\
\hline \multicolumn{5}{|c|}{ (b) $\alpha$-tocopherol } \\
\hline \multirow{2}{*}{ Hybrids } & \multicolumn{3}{|c|}{ Location } & \multirow{2}{*}{ Average } \\
\hline & Pieres & 9 de Julio & Tres Arroyos & \\
\hline Sideral & 888 & 869 & 926 & 894 \\
\hline Trisum & 904 & 750 & 874 & 843 \\
\hline Aromo & 843 & 736 & 856 & 812 \\
\hline Contiflor 9 & 736 & 776 & 813 & 775 \\
\hline ACA 884 & 774 & 690 & 782 & 749 \\
\hline Average & 829 & 764 & 850 & \\
\hline \multicolumn{5}{|c|}{ (c) $\beta$-tocopherol } \\
\hline \multirow{2}{*}{ Hybrids } & \multicolumn{3}{|c|}{ Location } & \multirow{2}{*}{ Average } \\
\hline & Pieres & 9 de Julio & Tres Arroyos & \\
\hline Sideral & 38 & 41 & 16 & 31.7 \\
\hline Trisum & 19 & 24 & 21 & 21.3 \\
\hline Aromo & 12 & 40 & 23 & 25.0 \\
\hline Contiflor 9 & 24 & 22 & 20 & 22.0 \\
\hline ACA 884 & 38 & 26 & 18 & 27.3 \\
\hline Average & 26.2 & 30.6 & 19.6 & \\
\hline
\end{tabular}

among hybrids for each location ranged from 8.2 to $8.8 \%$.

\section{Experiment II}

Significant $(P \leq 0.01)$ differences among hybrids and among locations $(P \leq 0.05)$ were detected. Hybrid*Location interaction was not significant, showing that hybrids had similar values in different locations. No significant differences among hybrids, locations and $\mathrm{HLI}(\mathrm{P} \geq 0.1)$ were detected in the group $\mathrm{HOH}$. Calculated GDD was $85 \%$.

CV (\%) values across locations for each hybrid ranged from 1.7 to $9.2 \%$ while $\mathrm{CV}$ values across hybrids for each location varied from 6.9.to 9.9\%. Maximum CV (\%) value across hybrids was lower than in Experiment I and similar to $\mathrm{CV}$ values across locations in this experiment.

\subsection{3. $\alpha$-tocopherol concentration}

\section{Experiment I}

Significant $(P \leq 0.01) \quad$ differences among hybrids and among locations $(P \leq 0.0001)$ were detected. Hybrid*Location interaction was significant $(P \leq 0.017)$.

Calculated GDD was $81 \%$, a similar value to the GDD for total tocopherol concentration.

CV (\%) values trough locations for each hybrid ranged from 7.7 to $16.6 \%$, and $\mathrm{CV}$ values trough hybrids for each location ranged from 8.3 to $9.3 \%$.

\section{Experiment II}

Significant $(P \leq 0.025)$ differences among hybrids and among locations $(P \leq 0.05)$ were detected. Hybrid*Location interaction was not significant. Calculated GDD was $85 \%$. 
The high values of GDD for total and $\alpha$ tocopherol concentrations in both experiments suggest that it could be possible to recommend the sowing of hybrids in a broad range of locations because although Hybrid*Location interaction was significant, it had a low value.

CV (\%) values across locations for each hybrid ranged from 3.2 to $9.7 \%$, and CV values across hybrids for each location ranged from 6.5 to $8.7 \%$.

\subsection{4. $\beta$-tocopherol concentration}

\section{Experiment I}

Significant $(P \leq 0.0001)$ differences among locations were detected while the differences among hybrids and Hybrid*Location interaction were not significant.

\section{Experiment II}

No significant differences among locations, hybrids and Hybrid*Location interaction were detected.

\subsection{Correlations between total and individual tocopherol concentrations and grain yield and oil content}

\section{Experiment I}

Total tocopherol concentration and grain yield were not significantly correlated $(P=0.9)$.

$\alpha$-tocopherol concentration was positively correlated with total tocopherol concentration $(r=0.992 ; \quad \mathrm{P}<0.0001 ; \mathrm{n}=84 ; \quad$ slope $=0.9$; intercept $=21$ ). $\beta$-tocopherol concentration was significant $(r=0.544 ; \quad P<0.0001 ;$ slope $=5$; intercept $=666$ ) and positively correlated with total tocopherol concentrations but the high value of the slope means that increases in the total tocopherol concentration correspond with low increases of $\beta$ tocopherol concentration. $\gamma$-tocopherol and total tocopherol concentration were not correlated.

Total tocopherol concentration and oil content were not significantly correlated, meaning that both traits could be independently selected. The lack of correlation could probably be explained by the broad variation in oil content of the different hybrids when data were pooled (Table Ilb). However, in three hybrids, ACA 884, Pyramid-1 and Morgan 742 , the total tocopherol concentration variations inversely accounted for oil content variations (Table VI), with the different proportion of variation explained for each one of them (43.8\%; , 45.3\% and $76.7 \%$ for ACA 884, Pyramid-1 and Morgan 742, respectively). Such a negative correlation has been found in sunflower (Marquard, 1990; Nolasco et al., 2004) and several mustards (Marquard, 1985). In the other hybrids, no significant correlation between both traits was observed $(P \geq 0.16)$ (Table $\mathrm{VI})$. These results were similar to those reported by Velasco et al. (2002).

\section{Experiment II}

Total and $\alpha$-tocopherol concentrations diminished when grain yield increased. Lineal relationships accounted for the variation of total tocopherol to a low extent $(38.6 \% ; \mathrm{P}<0.0001 ; \mathrm{n}=30$ and $46.5 \%$, $\mathrm{P}<0.0001 ; \mathrm{n}=30$ for total and $\alpha$-tocopherol, respectively). This variation was mainly explained by the negative relationship for each location across hybrids (Table VIla). Such results partly agree with Nolasco et al. (2004) who found a weak negative relationship between total and $\alpha$-tocopherol concentration and yield per plant. Total and $\alpha$ tocopherol concentrations increased at the Tres Arroyos location when oil content increased (Table VIIb). This result disagrees with previous research (i.e. Marquard, 1985, y Marquard, 1990) where negative relationships between tocopherol concentration and oil content are found). This inverse trend may be explained by a dilution of tocopherols in a higher oil quantity ( Nolasco et al., 2004).

$\alpha$-tocopherol concentration was positively and significantly correlated with total tocopherol concentration $(r=0.99 ; \mathrm{P}<0.0001 ; \mathrm{n}=40)$. $\beta$ tocopherol and total tocopherol concentration were not correlated.

In both experiments, variations in $\alpha$-tocopherol concentration accounted for variations in total tocopherol concentrations. The correlations between $\beta$ - and $\gamma$-tocopherol, which have a higher antioxidant activity and a lower vitamin activity than $\alpha$-tocopherol (Miller and Fick, 1997), were weak.

Results suggest that it would be possible to modify total and $\alpha$-tocopherol concentrations in $\mathrm{TH}$ with low variations across regions. . Environmental

Table VI

Correlation coefficient and significance between total, $\alpha$ and $\beta$-tocopherols and oil content (\% d.b.) for each of seven hybrids grown in four locations in Experiment I. *: $\mathrm{P}<0.05,{ }^{* *} \mathrm{P}<0.01$

\begin{tabular}{lccccccc}
\hline \multirow{2}{*}{ Parameter } & \multicolumn{9}{c}{ Hybrid } \\
\cline { 2 - 8 } & Paraíso 20 & Pyramid-1 & Morgan 742 & Contiflor 11 & Rancul & ACA 884 & Jaguel \\
\hline Total tocopherol & NS & $-0.67^{*}$ & $-0.88^{* *}$ & NS & NS & $-0.67^{*}$ & NS \\
$\alpha$-tocopherol & NS & $-0.71^{*}$ & $-0.87^{* *}$ & NS & NS & $-0.69^{*}$ & NS \\
$\beta$-tocopherol & NS & NS & $-0.71^{*}$ & NS & NS & NS & NS \\
\hline
\end{tabular}


Table VII

Correlation coefficient and significance between (a) total, $\alpha-$ and $\beta$ - tocopherols and grain yield $\left(\mathrm{kg} \mathrm{ha}^{-1}\right)$ and, (b) total, $\alpha$ - and $\beta$ - tocopherols and oil content (\% d.b.) for each of three locations where five hybrids were grown in Experiment II. ${ }^{*} \mathbf{P}<\mathbf{0 . 0 5},{ }^{* \star} \mathbf{P}<0,01$

(a) Grain yield

\begin{tabular}{lccc}
\hline \multirow{2}{*}{ Parameter } & \multicolumn{3}{c}{ Lociation } \\
\cline { 2 - 4 } & Pieres & 9 de Julio & Tres Arroyos \\
\hline Total tocopherol & $-0.78^{\star *}$ & $-0.65^{\star}$ & $-0.66^{*}$ \\
$\alpha$-tocopherol & $-0.75^{\star}$ & $-0.63^{\star}$ & $-0.67^{\star}$ \\
$\beta$-tocopherol & NS & NS & NS \\
\hline (b) Oil content & \multicolumn{3}{c}{} \\
\hline \multirow{2}{*}{ Parameter } & Lociation \\
\cline { 2 - 4 } & Pieres & 9 de Julio & Tres Arroyos \\
\hline Total tocopherol & NS & NS & $0.69^{\star}$ \\
$\alpha$-tocopherol & NS & NS & $0.69^{\star}$ \\
$\beta$-tocopherol & NS & NS & NS \\
\hline
\end{tabular}

variability existing in the Pampean Region, in Argentina, is sufficient to produce differences due to environmental effects. It would be necessary to make trials in other environments in different regions of Argentina to detect the variability in tocopherol concentrations among $\mathrm{HOH}$.

So, to produce sunflower oil content with high tocopherol concentrations the genotype is as important as the environment. In order to complete the information supplied in this paper, it is necessary to determine how environmental factors affect tocopherol concentrations and to know the relationship among them, among other quality traits and grain yield. The information given in this paper would allow plant breeders to interpret the variability in tocopherol concentrations obtained in different environments.

\section{ACKNOWLEDGEMENTS}

The research was developed in the context of the Specific Agreement of Cooperation between the Facultad de Ingeniería of the Universidad Nacional del Centro de la Provincia de Buenos Aires and the Facultad de Ciencias Agrarias of the Universidad Nacional de Mar del Plata. This work was supported by the Universidad Nacional del Centro de la Provincia de Buenos Aires, Universidad Nacional de Mar del Plata, Instituto Nacional de Tecnología Agropecuaria, Nidera S.A., Aceitera General Deheza S.A.and Morgan Mycogen S.A. Results were taken from Susana Nolasco M. Sc. Thesis (U.N.C.P.B.A., Advisor L Aguirrezábal ). Thanks are given to Victor Pereyra for providing seeds used in experiments. L.A.N.Aguirrezábal is member of the Consejo
Nacional de Investigaciones Científicas y Técnicas (CONICET, Argentina).

\section{REFERENCES}

AOAC - Association of the Official Analytical Chemists, (1990). Official Methods of Analysis of Association of the Official Analytical Chemists, Ed. W. Horwitz, $14^{\text {th }}$. Edn., Washington, D.C.

Agüero, M.E., Pereyra, V., Aguirrezábal, L.A.N., Lúquez, J. (1999). Rendimiento de grano y porcentaje de aceite en híbridos de girasol "alto oleico" en Argentina. AgriScientia, 14: 49-53.

ASAGIR, 2003. Segundo Congreso Nacional de Girasol, Hotel Hilton, Buenos Aires, 12-13 Agosto. 259 pág. www.criba.edu.ar/girasol/ResTal03/

AOCS - American Oil Chemists' Society, (1998). Official and Tentative Methods of the American Oil Chemists' Society $-5^{\text {th }}$ edition, Chicago, Illinois.

Box, G.E.P. (1954). Some theorems on quadratic forms applied in the study of analysis of variance. Problems. I. Ann. Math. Sytat, 25: 290-302. Mentioned in Gomes, P.F.(1978). Curso Estadística experimental. Editorial Hemisferio Sur. pp. 105-106.

Bramley, P.M., I. Elmadfa, A. Kafatos, F.J. Kelly, Y. Manios, H.E. Roxborough, W. Schuch, P.J.A. Sheehy and Wagner, K.H. (2000) Review Vitamin E. Journal of the Science of Food and Agriculture, 80: 913-938.

Cochran, W.G. and Cox, G.M. (1992). Experimental Designs. Second Edition. John Wiley \& Sons, Inc. New York., pp. 545-555

Cole G., Coughlan, S., Frey, N, Hazebroek, J. and Jennings, C. (1998). New sunflower and soybean cultivars for novel vegetable oil types. Fett/Lipid, 100: 177-181.

De Villiers, J.B.M.; Du Toit, L.J. and Du Plessis, L.M. (1989).The composition and processing characteristics of high oil acid sunflower seed and its products. Journal of Food Science \& Nutrition, pp. 9-11 
Demurin Y., Skoric, D., Karlovic, D. (1996).Genetic variability of tocopherol composition in sunflower seeds as a basis of breeding for improved oil quality. Plant. Breeding, 115: 33-36

Dolde, D., Vlahakis,C., Hazebroek, J. (1999).Tocopherols in breeding lines and effects of planting location, fatty acid composition, and temperature during development. Journal of the American Oil Chemists' Society 76: 349-355

Dorrell, D.G., Vick, B.A. (1997)- Propierties and processing of oilseed sunflower, In: Sunflower Technology and Production. Editor: Schneiter, A.A. ASA, CSSA y SSSA, Madison, Wisconsin, USA. pp. 709-746.

Eitenmiller, R.R. (1997) Vitamin E content of fats and oils - Nutritional Implications. Food Technology, 51 (5): 7881.

Fehr, W.R. (1987). Heritability, in Principles of cultivar development. Volume I: Theory and Technique. Mcmillan Publishing Company. Division of Mcmillan, New York. pp. 95-105

Gustone, F.D.; Harwood, J.L. and Pady, F.B. (1994). The Lipid Handbook. Second Edition Chapman \& Hall . London.

Holló, J.; Perédi, J.; Kóvári, K., Recseg, K. (1998). High oil and high linoleic sunflower varieties and hybrids in Hungary- Characteristics. Olaj, Szappan, Kozmetika, 47: $1-6$

Jáky, V.M., Kurnik, E.; Perédi, J.; Szántó, I., Szabó, R., Pálao, L. (1980). Untersucungsergebnisseuber-Sonnenblumen. Fette-eifenAnstrichmittel, 82: 110-116

Kamal-Eldin, A., Appelqvist, L.A. (1996). The chemistry and antioxidant properties of thocopherols and tocotrienols. Lipids, 31: 671-701

Kandil, A., Ibrahum, F.A., Marquard, R., Taha, R.S. (1990). Response of some quality traits of sunflower seeds and oil to different enviroments. Journal Agronomy \& Crop Science, 164: 224-230

Lúquez, J.; Aguirrezábal, L.A.N.; Aguero, M.E.; Pereyra, V. (2002). Stability and adaptability of cultivars in nonbalanced yield trials. Comparison of methods for selecting "high oleic" sunflower hybrids for grain yied and quality. J. Agronomy and Crop Science 188: 225-234.

Mariotti, J.A. (1986). Fundamentos de genética biométrica. Aplicaciones al mejoramiento genético vegetal. Secretaría General de la Organización de los Estados Americanos. Programa Regional de Desarrollo Científico y tecnológico. Whashington, D.C. pp.33-48
Marquard, R. (1990). Untersuchungen tiber dem Einfluss von Sorte und Standort auf den Tocopherogehalt verschiedener Pflanzanole Fat Science and Technology, 92:452-455

Marquard, R., Schuster, W., Seibel, K.H. (1985). The influence of temperature and photoperiod on fat content, fatty acid composition and tocopherols of rapeseed (Brassica napus) and nustard species (Sinapis alba, Brassica juncea and Brassica nigra). Agrochemica, 29: 145-153

Mascioli, S. (2001) . Tocoferoles y relación tocoferolesácido linoleico en el aceite de híbridos de girasol $(\mathrm{He}$ lianthus annuus $L$.) tradicional, medio y alto oleico, Efecto de variaciones en la temperatura nocturna en condiciones de campo. Tesis de grado. Licenciatura en Ciencias Biológicas., Facultad de Ciencias Exactas y Naturales, Universidad Nacional de Mar del Plata. $53 \mathrm{pp}$.

Mercau, J.L.; Sadras, V.O.; Satorre, E.H.; Messina, C.; Balbi, C.; Uribelarrea M. , Hall, A.J. (2001). On-farm assessment of regional and seasonal variation in sunflower yield in Argentina, Agricultural Systems, 67: 83103

Miller, J.F, Fick, G.N. (1997) The genetic of sunflower, In Sunflower Technology and Production. Editor: Schneiter, A.A. ASA, CSSA y SSSA, Madison, Wisconsin, USA. pp. 441-496.

Nagao, A., Yamazaki, M. (1983). Lipid of sunflower seed produced in Japan. Journal of American Oil Chemists' Society, 60: 1654-1658.

Nolasco, S.M., Aguirrezábal L.A.N., Crapiste G.H. (2004). Tocopherol oil concentration in field-grown sunflower is accounted for by oil weight per seed. Journal of American Oil Chemists' Society, 81: 1045-1051.

Purdy, R.H. (1986). High oleic sunflower: physical and chemical characteristics. Journal of American Oil Chemists' Society, 63: 1061- 1066

Robertson, J. , Morrison, W. (1979). Analysis of oil content of sunflower seed by wide-line NMR. Journal of American Oil Chemists' Society 56: 961-964

Velasco, L., Fernández-Martínez, J.M., García-Ruiz, R., Domínguez, J. (2002). Genetic and environmental variation for tocopherol content and composition sunflower commercial hybrids. Journal of Agricultural Science, 139(4): 425-429.

Recibido: Abril 2005 Aceptado: Enero 2006 